\title{
URBAN TERABITHIA, RUANG RETREAT KAWASAN TAMBORA
}

\author{
Edrik Tasbun ${ }^{1)}$, Agustinus Sutanto ${ }^{2)}$ \\ 1)Program Studi S1 Arsitektur, Fakultas Teknik, Universitas Tarumanagara, durirudi@yahoo.com \\ 2)Program Studi S1 Arsitektur, Fakultas Teknik, Universitas Tarumanagara, berpikirteoripraksis@gmail.com
}

\begin{abstract}
Abstrak
Kecamatan Tambora yang menjadi kawasan dengan tingkat penduduk paling padat se-Asia Tenggara ini, merupakan salah satu area yang didominasi permukiman informal di kota Jakarta. Perkembangan kota yang semakin kapitalis membuat adanya ketimpangan pada sektor formal dan informal, sehingga menimbulkan permasalahan sosial, mental, dan lainnya. Tambora Retreat Spaces dengan pendekatan arsitektur Urban Accupuncture menjadi wadah dengan menciptakan sebuah realita lingkungan baru bagi informalitas untuk membantu mereka memperkuat perannya pada bagian di dalam kota. Proyek ini menghadirkan Urban zen garden dan biophilic design sebagai media retreat pasif dan technology retreatment untuk media retreat aktif. Tempat ini juga berperan dalam menggantikan peran ruang terbuka serta fasilitas ruang ketiga bagi mereka yang hilang digantikan oleh permukiman warga yang semakin padat setiap tahunnya. Proyek ini juga berfokus untuk menciptakan sebuah media ruang tumbuh masyarakat dari segala umur dan status sosialnya dalam kehidupan masyarakat, dengan berlandaskan konsep Ville Spatiale dari Yona Friedman untuk menjadi wadah interaksi, rehabilitasi, dan terinspirasi.
\end{abstract}

\section{Kata Kunci: Alam; Rehabilitasi; Ruang Tumbuh; Teknologi}

\begin{abstract}
Tambora District, which is the most densely populated region in Southeast Asia, is one of the informal sectors in the city of Jakarta. The development of an increasingly capitalist city, so that there are imbalances in the formal and informal sectors, causing social, mental, and other problems. Tambora Retreat Spaces with the Urban Accupunchture architecture approach becomes a forum by creating a new environmental reality for the informal sector to help them strengthen their role in the inner city. This project presents Urban zen garden and biophilic design as a passive media retreat and technology retreat for active media retreats. This place also plays a role in replacing the role of open space and third-places facilities for those who are lost are replaced by residential settlements that are increasingly congested every year. The project also focuses on creating a media for community growth space of all ages and social status in community life, based on the Ville Spatiale concept of Yona Friedman to become a forum for interaction, rehabilitation, and inspiration
\end{abstract}

Keywords: Growth Spaces; Nature; Rehabilitation; Technology

\section{PENDAHULUAN Latar Belakang}

Kecamatan Tambora yang menjadi kawasan dengan tingkat penduduk paling padat se-Asia tenggara ini, merupakan salah satu area yang didominasi permukiman informal di kota Jakarta. Sebuah kawasan di perkotaan dengan kualitas lingkungan hidup yang buruk, dari hunian yang padat, sistem sanitasi yang buruk, dan tidak tersedianya ruang tumbuh dan hijau di sekitar. Perkembangan kota yang semakin kapitalis, sehingga adanya ketimpangan pada sektor formal dan informal, sehingga menimbulkan permasalahan sosial, mental, dan lainnya pada sektor informal. Sektor informal yang semakin menjadi sebuah kaum kerja paksa (Pekerja dengan 
kualitas hidup yang buruk) yang mampu memberikan dampak yang buruk bagi keberlangsungan sebuah kota. Dengan latar belakang tersebut, peran sebuah Ruang Ketiga, berdasarkan teori dari Ray Oldenburg, menjadi sebuah solusi yang tepat dalam permasalahan tersebut. Pada teori mengenai Third Places dari Ray Oldenburg, mengatakan adanya sebuah wadah yang dapat menjadi sebuah pemersatu dan transisi dari setiap golongan untuk melupakan level dan status sosialnya. Namun pada era kehidupan pada saat ini, konsep tersebut lebih terlihat seperti mustahil, dimana setiap manusia tidak dapat melepas statusnya maupun berinteraksi satu sama lain tanpa suatu kepentingan tertentu dibaliknya.

Berlokasi di Kecamatan Tambora, tepatnya di bantaran sungai Kalianyar yang bertepatan dengan Kelurahan Kalianyar dan Grogol Petamburan, dimana daerah ini merupakan daerah terpadat se-Asia Tenggara dengan kondisi yang benar- benar memprihatinkan. Dengan latar belakang tersebut, proyek ini akan membahas bagaimana sebuah realita lingkungan baru, yang tidak hanya menjadi sebuah wadah ruang ketiga, namun dapat menghadirkan sebuah ruang untuk rehabilitasi dan interaksi setiap masyarakat untuk menunjang sebuah kehidupan kota.

\section{Rumusan Permasalahan}

Berdasarkan latar belakang yang dijelaskan sebelumnya, maka dapat beberapa rumusan masalah yang menjadi dasar latar belakang proyek;

a. Bagaimana memberikan sebuah media ruang rehabilitasi untuk masyarakat sekitar Kecamatan Tambora, dimana mereka mendapatkan sebuah ruang yang layak untuk menyeimbangkan kehidupan mereka.

b. Bagaimana peran ruang tersebut terhadap masyarakat sekitar, serta dampaknya pada kehidupan sebuah kota, serta ruang seperti apa yang dapat menjadi sebuah lingkungan ruang tumbuh yang layak bagi mereka.

c. Bagaimana Teori dari Ray Oldenburg mengenai Ruang Ketiga dapat berperan dalam menyeimbangkan kehidupan pada sebuah kota, dengan kaidah-kaidahnya dapat berperan penting di tengah masyarakat kota.

\section{Tujuan}

Dengan latar belakang karakter masyarakat setampat, proyek ini ingin menghadirkan sebuah fasilitas rehabilitasi, sehingga pengguna mendapatkan sebuah media rehabilitasi, yang dapat membantu mereka dalam segi ekonomi, sosial, dan psikologi dalam memperkuat perannya dalam kehidupan sebuah kota. Sebuah proyek yang berfokus untuk memberikan sebuah ruang tumbuh masyarakat Tambora yang layak.

\section{KAJIAN LITERATUR}

\section{Pengertian Open Architecture}

Open: Terbuka, tidak tertutup, diketahui dengan baik, transparan, publik, berhubungan dengan di atas Architecture: Seni dari bangunan, penggabungan antara aturan konstruksi tradisional dan ilmiah dalam bahan dasar rancangan. Open Architecture: Bangunan yang dapat di akses publik, tidak tertutup Budaya dan filosofi keterbukaan 'openness' mulai muncul pada tahun 60an yang diawali dengan budaya 'open work' dan tahun 90-an revolusi digital turut memacu budaya keterbukaan dalam produksi dan berbagi. Dalam disiplin ilmu arsitektur, beberapa praktisi mulai menentang peraturan yang baku, peran antara yang ditugaskan dengan perancang. Dalam mengexplorasi konsep tentang keterbukaan 'openness' dalam arsitektur, para peneliti membandingkan dengan tiga kasus, yaitu: Open Form, Open City, dan Open Source. 
Open Form

Open form merupakan konsep / hal yang berlawanan dengan Closed Form, teori yang menjadi perdebatan dan standarisasi dalam pembangunan perumahan pasca perang di Polandia yang dinilai menelantarkan individualitas dan keunikan manusia. Peneliti menghubungkan Open Form dengan interaksi dan koneksi antara manusia, lebih mengarah kepada kondisi sosial.

\section{Open City}

konsep ini muncul ketika suatu komunitas mengkritisi praktisi kontemporer arsitektur dan pendidikan yang didominasi kepentingan komersil. Atas dasar hal tersebut suatu grup membeli lahan dan menamainya'open city'. Open city menjadi tempat untuk kebebasan berpikir, penelitian, dan eksperimen untuk arsitektur yang tidak muncul dari kencenderungan mementingkan pendidikan.

\section{Open Source}

merupakan sumber informasi yang bisa di akses publik dan digunakan untuk kepentingan. Berikut adalah diagram hubungan antara ketiga poin di atas.

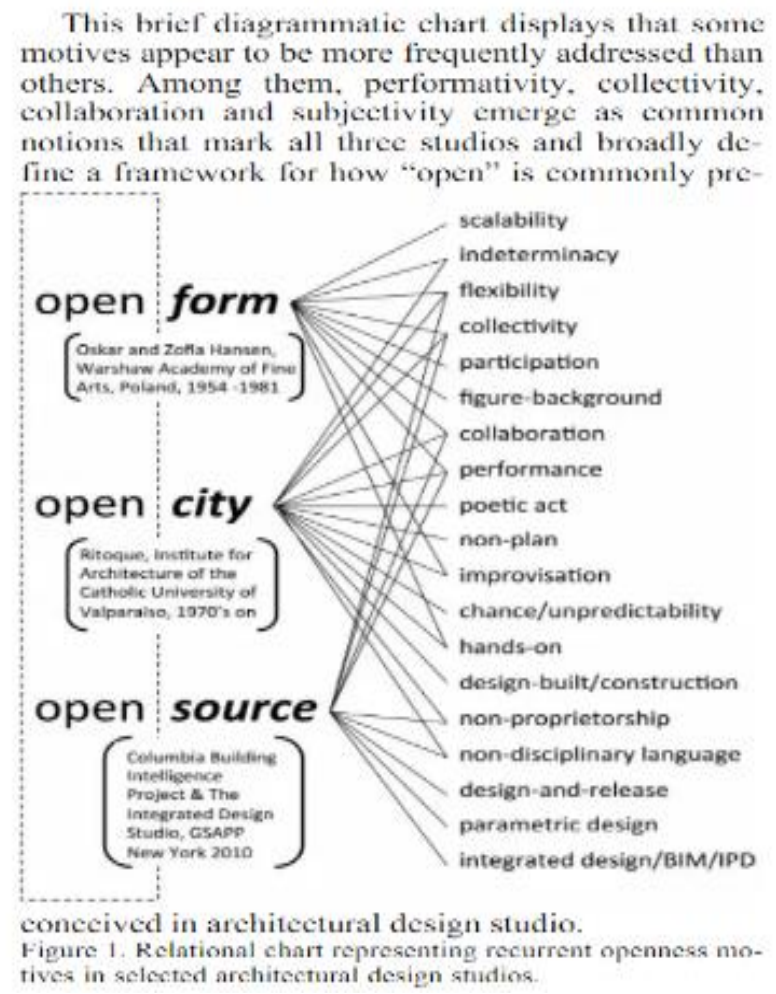

Gambar 1. Diagram Open Architecture

Sumber: Dok.Google.com

\section{Pengertian Open Architecture for The Third Places}

Open Architectures for The Third Places bagi masyarakat kota yang berfungsi sebagai ruang antara First Places ( Tempat tinggal) dan Second Places (Tempat bekerja). ${ }^{1}$ Third Places juga dapat berfungsi sebagai program pembantu masyarakat kota agar bersifat humanis, terbuka, dinamis, dan juga produktif. Selain itu program tersebut harus mampu beradaptasi dengan aktivitas dan tipologi yang ada, sehingga menciptakan sebuah fasilitas lingkungan yang tepat. Third Places merupakan sebuah program pendukung yang menjadi fasilitas dan penunjang

\footnotetext{
${ }^{1}$ Oldenburg, Ray. (1991). The Great Good Place. New York, Amerika Serikat (USA): Marlowe dan Company
} 
keseharian masyarakat. Namun program ini bukan hadir untuk menyelesaikan permasalahan sosial di dalam suatu lingkungan. Third Places adalah tempat informal dimana orang berkumpul antara rumah dan kerja. Dalam bab ini, Oldenburg mengeksplorasi karakteristik mereka:

a. On Neutral Ground

Pada aspek ini dimana sebuah program yang ada pada bangunan Third Places harus bersifat netral tanpa adanya kasta sosial atau lainnya pada setiap individu di dalamnya.

b. The Third Place as Leveler

Pada Third Places setiap individu menjadi terkait satu dengan lainnya, tanpa adanya perbedaan tingkatan dari mulai aspek usia dan lainnya.

c. Conversation is the Main Activity

Sebuah wadah yang mampu memberikan fasilitas yang dapat menunjang interaksi sosial di dalamnya. Pada aspek ini sebuah konsep Third Places harus mampu mendorong interkasi setiap individu dari segala kalangan, usia, dan lainnya.

d. Accessibility and Accommodation

Aksesbilitas dari tempat harus mudah dijangkau oleh lingkungan setempat. Selain itu akses tersebut harus memperhatikan segala kalangan termasuk anak-anak sampai lansia.

e. The Regulars

Aktifitas dan fungsi pada Third Places harus menjadi sebuah fungsi yang umum oleh segala kalangan dan usia. Aspek ini juga mempertimbangkan setiap individu pendatang dari luar. Dimana setiap fungsinya dapat dilakukan dengan baik. Sesuatu fungsi yang telah umum dilakukan atau bisa dipakai oleh segala kalangan dari faktor usia sampai kasta, serta lainnya.

f. A Low Profile

Tempat ketiga secara karakteristik sederhana. Tempat ketiga dapat memberikan sebuah kesan menerima semua jenis-jenis individu, dari berbagai lapisan masyarakat.

g. The mood is playful

Sebuah tempat yang mampu memberikan suasana ruang tenang dan penuh dengan kegiatan yang atraktif serta interaktif.

\section{Teori Anoniminitas}

Dalam teori Ray Oldenburg, dimana beliau menyatakan sebuah kriteria Third Places as Neutral Places. Kriteria tersebut menyatakan dimana sebuah fasilitas tersebut dapat menjadi tempat yang netral untuk segala kalangan, seperti orang kaya dan miskin yang masuk sebuah lingkungan realita lain dimana mereka dapat melupakan strata sosial yang ada dan melakukan aktifitas serta berinteraksi satu sama lain. Teori anonimitas merupakan sebuah teori yang berkesimpulan bahwa setiap manusia dapat benar-benar dapat berinteraksi sosial hanya pada sebuah realita lingkungan baru. ${ }^{2}$ Realita lingkungan baru yang dimaksudkan tersebut pun merupakan sebuah dunia virtual baru, yaitu dunia dalam media sosial. Menurut Teori tersebut media sosial merupakan sebuah Dunia Anonimus (Samaran/ tanpa identitas), dimana setiap individu dapat meninggalkan seluruh label kehidupan di dunia asli mereka (Stratifikasi Sosial) dan masuk ke sebuah realita baru yaitu dunia virtual. ${ }^{3}$

Dengan Teori ini, projek ini berharap dapat menhadirkan sebuah wadah realita yang dapat memberikan kesempatan kepada setiap golongan untuk terlepas dari label kehidupannya dan saling berinteraksi. Dengan bantuan media sosial, dimana setiap individu menjadi anonimus dan dapat saling berinteraksi, sehingga Third Places as Neutral Ground untuk menghubungkan strata sosial tersebut.

\footnotetext{
${ }^{2}$ Pramono, Dimas. (2007). Teori Anoniminitas pada Media Sosial. 2008 : SKRIPSI ILMU KOMUNIKASI . BAB VI, 120- 123.

${ }^{3}$ Ibid., ; hal. 121.
} 


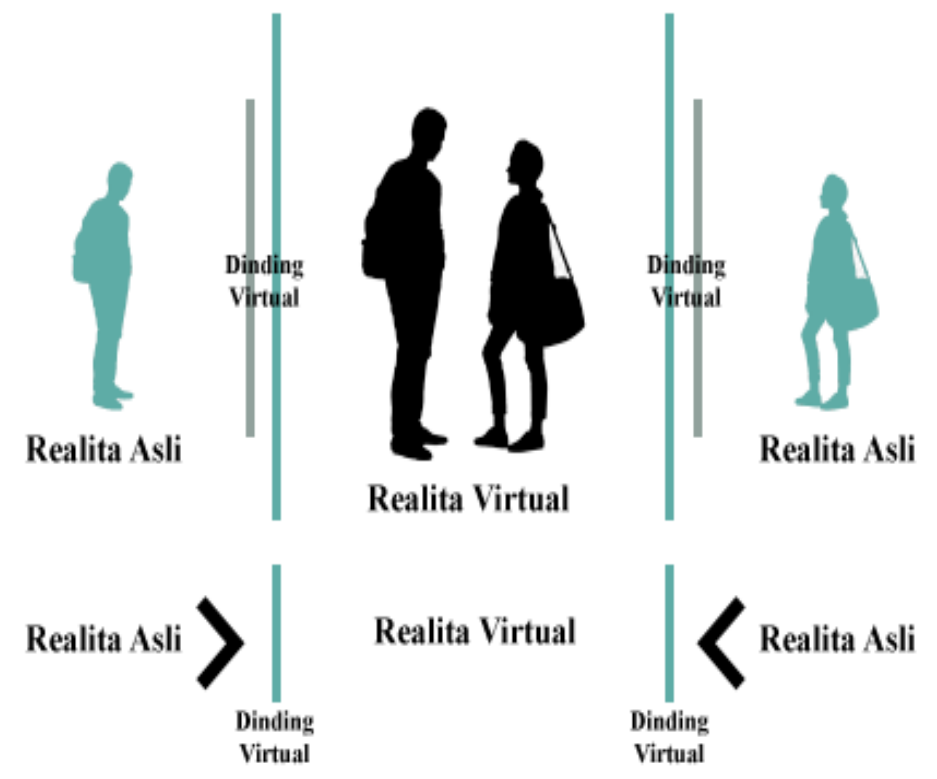

Gambar 2. Sketsa Teori Anoniminitas

Sumber: Penulis, 2020.

\section{METODE}

Adapun metode perancangan yang digunakan dalam penelusuran ide hingga konsep adalah sebagai berikut:

\section{Metode Urban Accupuncture}

Urban Accupunchture: Kota adalah sumber inspirasi yang sekaligus memberikan makna kehidupan didalamnya. Kota memiliki organ-organ seperti bangunan dan berbagai fungsinya, memiliki aliran 'pembuluh darah' seperti infrastruktur jalan, memiliki 'jiwa' melalui orangorang yang hidup didalamnya, sehingga kota dapat dideskripsikan seperti organisme yang terdiri dari berbagai elemen pembentuk struktur 'tubuh' kehidupan. ${ }^{4} U$ rban Acupuncture pada dasarnya merupakan teori environmentalisme perkotaan, yaitu menggabungkan ilmu perkotaan kontemporer dengan ilmu pengobatan tradisional China. Dengan melihat kota sebagai organisme hidup, Urban Acupuncture ditujukan dapat menggerakkan kembali "sirkulasi" yang tersumbat akibat mekanisme kerja kota yang buruk. Konsep ini menjadi dasar pada perancangan proyek ini, dengan metode urban Infill untuk mengikuti pola solid dan void pada bangunan sebelumnya, sehingga menciptakan sebuah ruang lingkungan baru, tanpa merusak struktur kota sebelumnya.

\section{Metode Biophilic Design}

Proyek ini menghadirkan Urban Zen Garden dan Biophilic Design sebagai media retreat pasif memanfaatkan unsur alam. Unsur alam dalam sebuah Biophilic Design pada seluruh sirkulasi pada bangunan dan urban Zen Garden. Serta tersedianya sebuah ruang green komunal amphiteater bagi masyarakat untuk menggantikan sebuah peran ruang terbuka dan komunal yang telah hilang di kawasan yang dipenuhi oleh hunian tersebut. Biophilic Design/ Desain Biophilic adalah konsep yang digunakan dalam industri bangunan untuk meningkatkan konektivitas penghuni ke lingkungan alam melalui penggunaan sifat langsung, sifat tidak

\footnotetext{
${ }^{4}$ Casagrande, Marco.(2015). Paracity- Urban Acupunchture. New York, Amerika Serikat (USA) : Oil Forest League
} 
langsung, serta kondisi ruang dan tempat. Digunakan baik pada skala bangunan atau kota bahwa ide ini memiliki manfaat kesehatan, lingkungan, serta ekonomi untuk penghuni bangunan.

\section{Metode Urban Infill}

Urban Infill adalah metode mendirikan bangunan dengan mengisi sebuah ruang pada wilayah yang sekelilingnya terdapat bangunan eksisting dan menitikberatkan pada keselarasan antara hasil rancangan dan lingkungan sekitar. ${ }^{5}$ Building Infill merupakan hal yang tepat mengingat keduanya sama-sama menitikberatkan pada keselarasan lingkungan. Tujuan dari ini adalah untuk lebih memahami tentang bagaimana penerapan dari metode building infill sebagai salah satu upaya untuk menciptakan sesuatu, tanpa merusak struktur kota yang sudah ada sebelumnya.

Metode ini merupakan sebuah metode yang paling tepat dalam menciptakan sebuah bangunan pada konteks kawasan Tambora. Dimana dapat mendirikan sebuah bangunan yang dapat memberikan media rehabilitasi pada area sekitar, tanpa merusak struktur kota dan bangunan sebelumnya. Metode ini dilakukan karena adanya beberapa faktor sebagai berikut :

a. Keterbatasan lahan perancangan pada kawasan, sebagian besar lahan yang berada, telah dialih fungsikan sebagai hunian masyarakat dan bangunan lainnya.

b. Menciptakan sebuah bangunan, tanpa merusak Fisrt Places (Hunian) dan Second Places (Tempat Bekerja) masyarakat sekitar kawasan Tambora.

\section{Studi Kasus}

Proyek ini terinspirasi dari Spatial City dari Yona Friedman, serta the new Babylon dari Constant Niewenhuys, untuk menciptakan sebuah ruang tumbuh masyarakat, untuk beraktifitas dan kebebasan dalam interaksi maupun berekspresi. Dengan sebuah metode pertumbuhan kota secara vertikal, tanpa merusak lingkungan atau struktur kota yang ada sebelumnya.
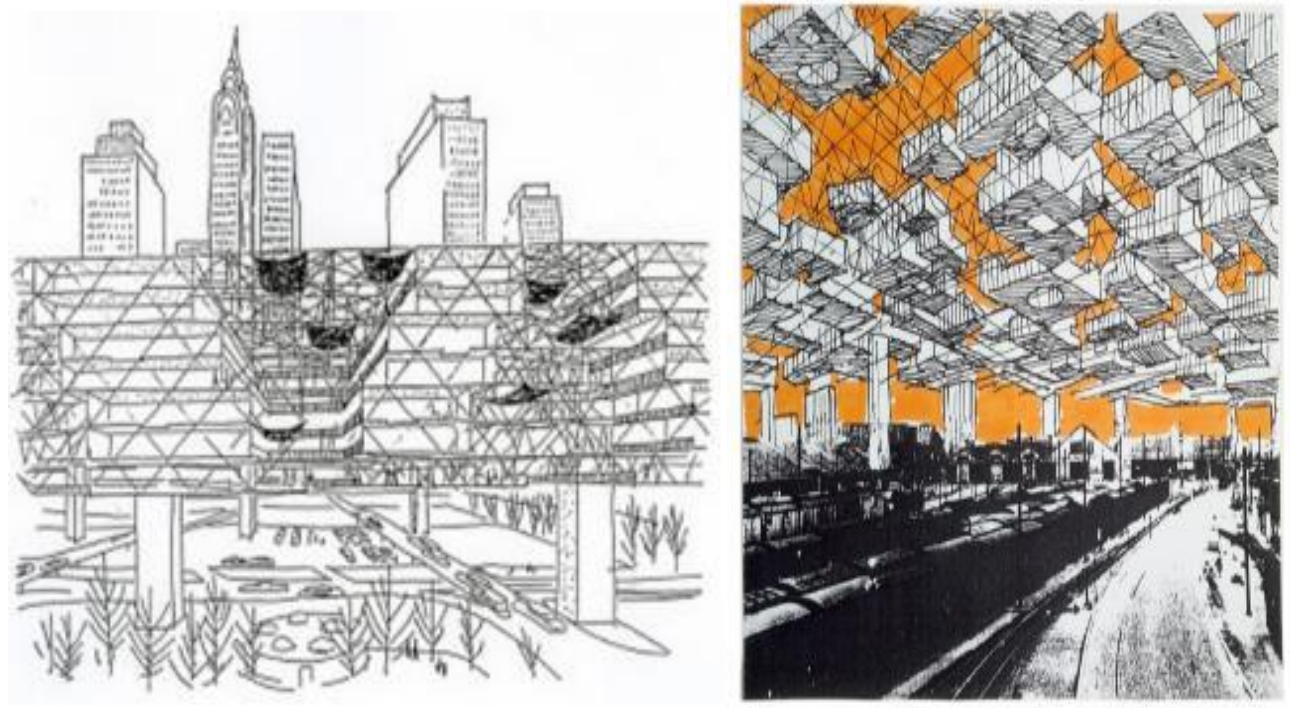

Gambar 3. Sketsa Konsep Ville Spatiale

Sumber: Yona Friedman, 2008

${ }^{5}$ Pallete 2030.(2017). Urban Infill for City Growth. 2030 PALLETE, 1-3 

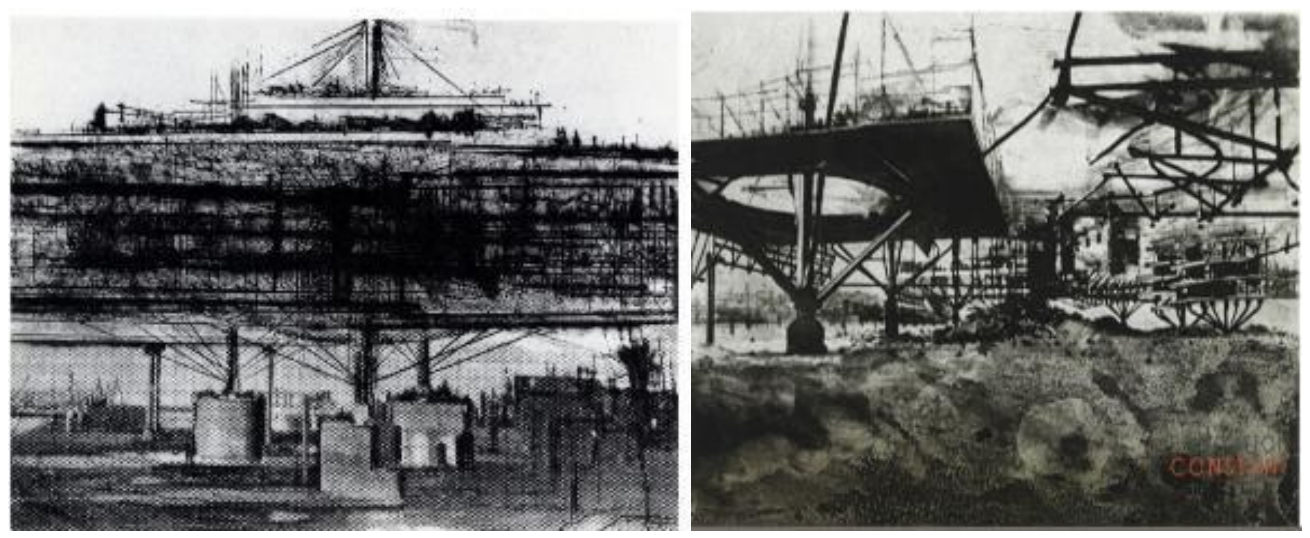

Gambar 4. Sketsa Konsep The New Babylon

Sumber: Constant Niewenhuys.

\section{DISKUSI DAN HASIL Konsep Perancangan}

Kecamatan Tambora yang menjadi kawasan dengan tingkat penduduk paling padat se-Asia tenggara ini, merupakan salah satu sektor informal di kota Jakarta. Kawasan ini dikenal dengan padatnya hunian, sistem infrastruktur serta kualitas lingkungan hidup yang buruk. Perkembangan kota yang semakin kapitalis, sehingga adanya ketimpangan pada masyarakat sektor formal dan informal, sehingga menimbulkan permasalahan sosial, lingkungan, dan lainnya.

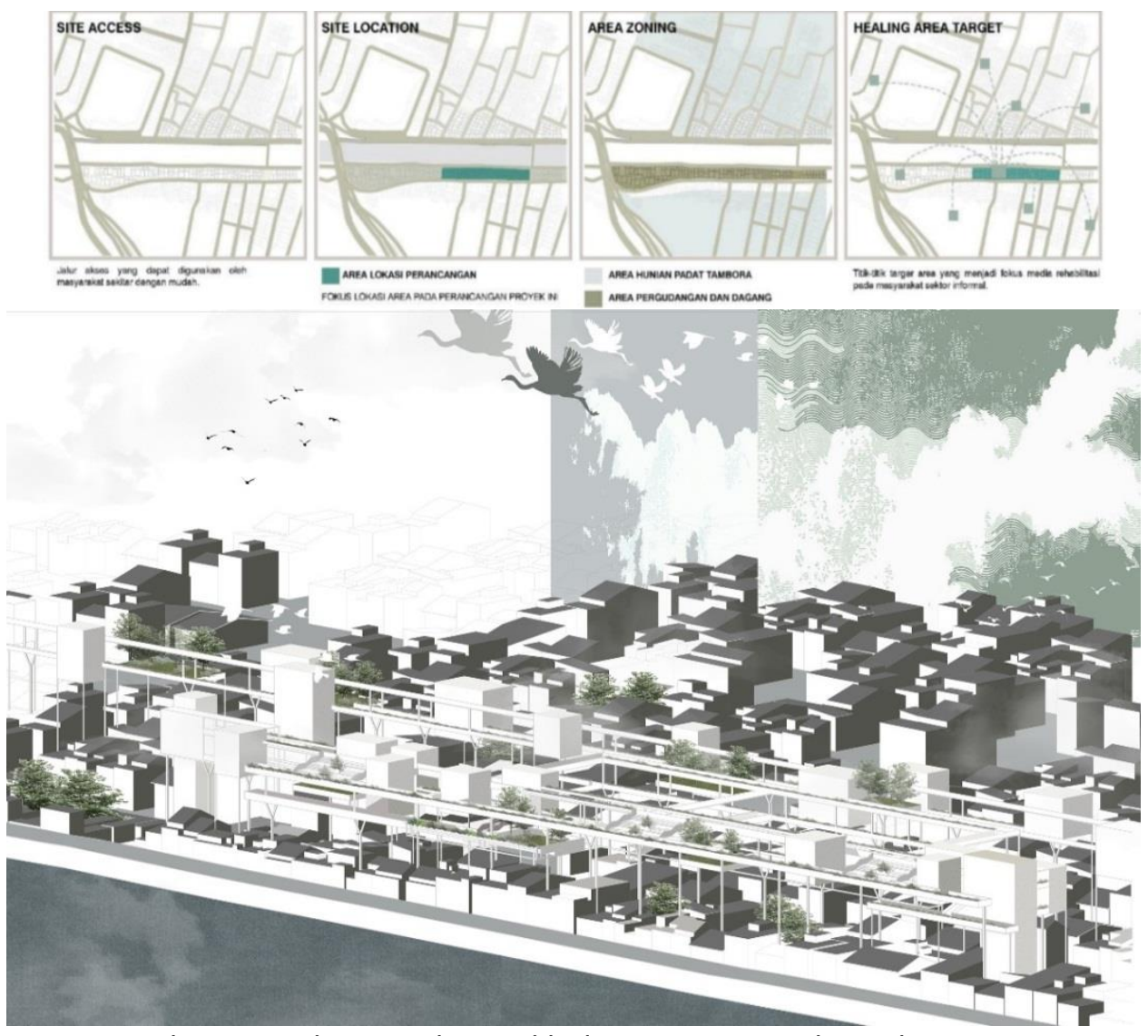

Gambar 5. Analisa Tapak Terpilih dan Strategi Pembentukan Massa Sumber: Penulis, 2020. 
Urban Terabithia: Tambora Retreat Spaces dengan pendekatan arsitektur Urban Accupunchture menjadi wadah yang menciptakan sebuah realita lingkungan baru bagi sektor informal untuk membantu mereka memperkuat perannya pada bagian di dalam kota. Dengan Scafolding Skleton Structure, bangunan ini menciptakan sebuah ruang tanpa merusak struktur kawasan yang lama, sesuai pola solid dan void bangunan. Proyek ini menghadirkan Urban Zen Garden dan Biophilic Design sebagai media retreat pasif memanfaatkan unsur alam. Selain itu teknologi Retreatment $P O D$ terbagi menjadi entertainment $P O D$, virtual \& augmented reality $P O D$, consultation dan community $P O D$ untuk media retreat aktif. Proyek ini berfokus untuk menciptakan sebuah media ruang tumbuh masyarakat dari segala umur dan status sosialnya dalam kehidupan masyarakat kota. Sebuah ruang ketiga yang dapat menjadi wadah interaksi, rehabilitasi, dan terinspirasi. Berikut merupakan sebuah konsep dasar sistem Konstruksi Scafolding Skleton Structure. Sebuah sistem konstruksi utama yang terdiri dari susunan kolom beton yang saling berhubungan pada area lokasi kawasan Tambora.
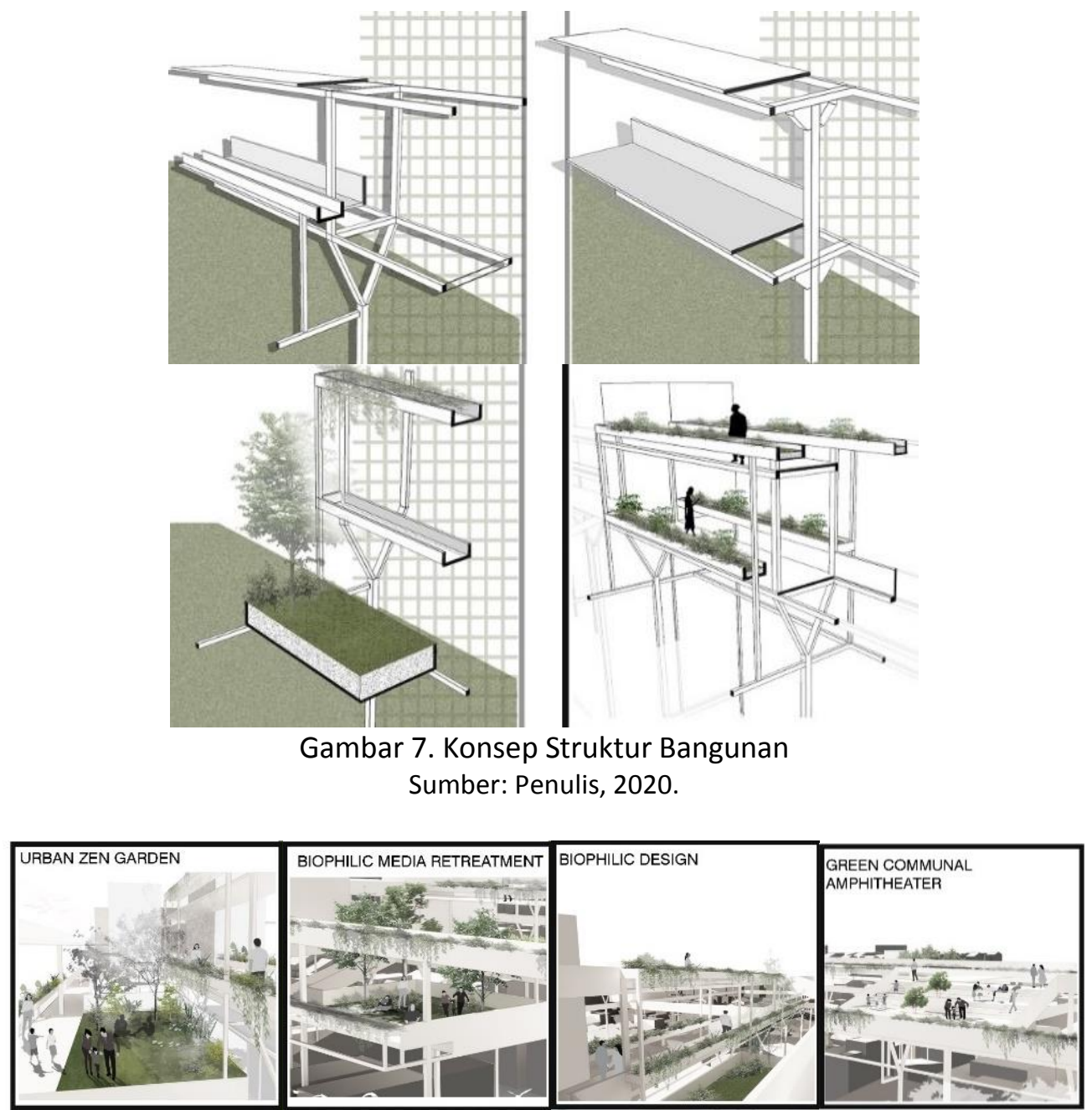

Gambar 8. Strategi Biophilic Design

Sumber: Penulis, 2020.

Media pasif dengan unsur alam dalam sebuah Biophilic Design pada seluruh sirkulasi pada bangunan dan urban zen garden. Serta tersedianya sebuah ruang green communal amphiteater bagi masyarakat untuk menggantikan sebuah peran ruang terbuka dan komunal yang telah hilang di kawasan yang dipenuhi oleh hunian tersebut. Technology Retreatment $P O D$ merupakan sebuah wadah aktif dengan memanfaatkan metode teknologi sebagai media rehabilitasi, interaksi global dan hiburan, dibagi menjadi: Entertainment $P O D$, Virtual \& 
Augmented Reality POD, Consultation dan Community POD. Memanfaatkan sebuah Teknologi dalam memberikan sebuah media rehabilitasi, hiburan, dan interaksi komunitas. Media Teknologi yang mampu memberikan sebuah sarana konsultasi ekonomi dan sosial, serta sarana komunikasi global masyarakat sektor informal maupun formal dalam berinteraksi tanpa mengenal status sosial maupun latar belakang (Teori Anoniminitas).

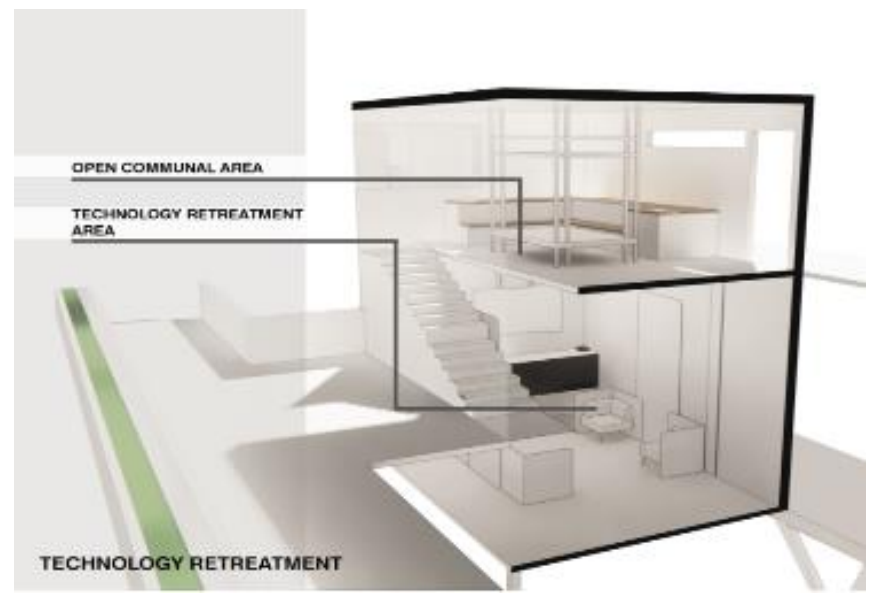

Gambar 9. Retreatment POD Detail

Sumber: Penulis, 2020.

Technology Retreatment $P O D$, merupakan sebuah media rehabilitasi dan interaksi menggunakan sebuah Teknologi, dibagi menjadi beberapa bagian;

Tabel 1. Penerapan Konsep Technology Retreatment POD Pada Rancangan

Jenis Teknologi

1. Virtual \& Augmented Reality POD

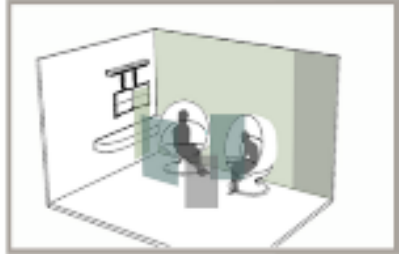

VIRTUAL \&

AUGMENTED REALITY

POD

\section{Penerapan Dalam Rancangan}

Memanfaatkan sebuah Teknologi augmented \& virtual reality, untuk menciptakan sebuah wadah rehabilitasi dengan memanfaatkan Technology Rehabilitation method. Sehingga setiap individu dapat merasakan sebuah realita lingkungan baru lewat bantuan teknologi untuk rehabilitasi dan konsultasi. Serta dengan bantuan teknologi dalam menciptakan sebuah realita lingkungan dalam berinteraksi sosial sehingga masyarakat sektor informal maupun formal dalam berinteraksi tanpa mengenal status sosial maupun latar belakang.
2. Consultation POD

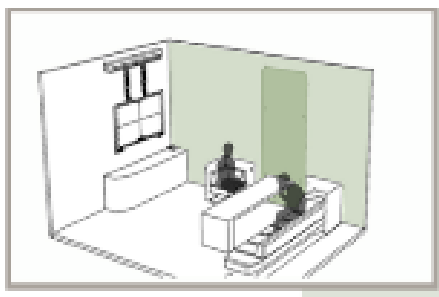

CONSULTATION POD
Consultation $P O D$ sebuah media rehabilitasi yang bermanfaat untuk menstabilkan kondisi mental masyarakat sektor informal, secara langsung maupun tidak langsung. Tujuan media ini untuk memperkuat masyarakat sektor informal dalam bidang sosial maupun ekonomi lewat media verbal. 


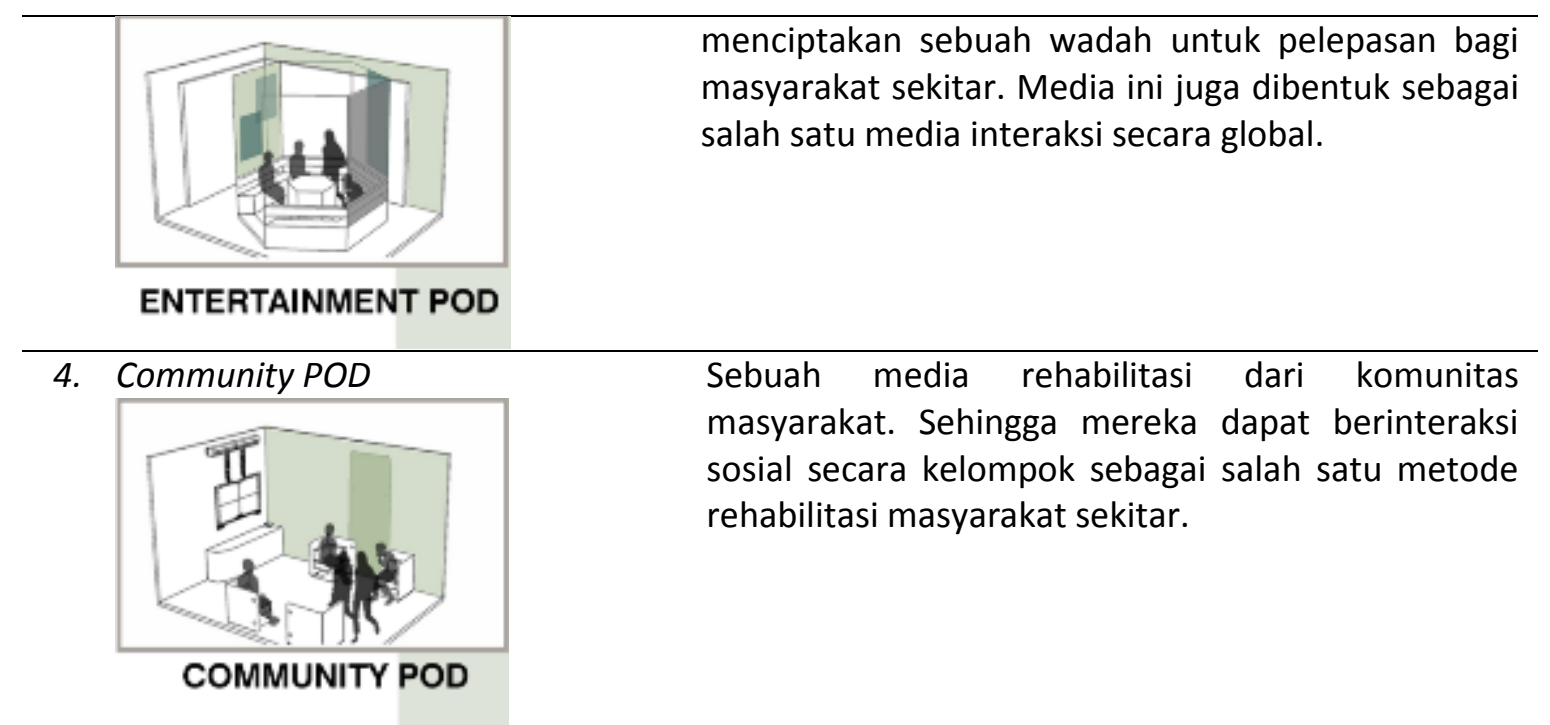

Sumber: Penulis, 2020.

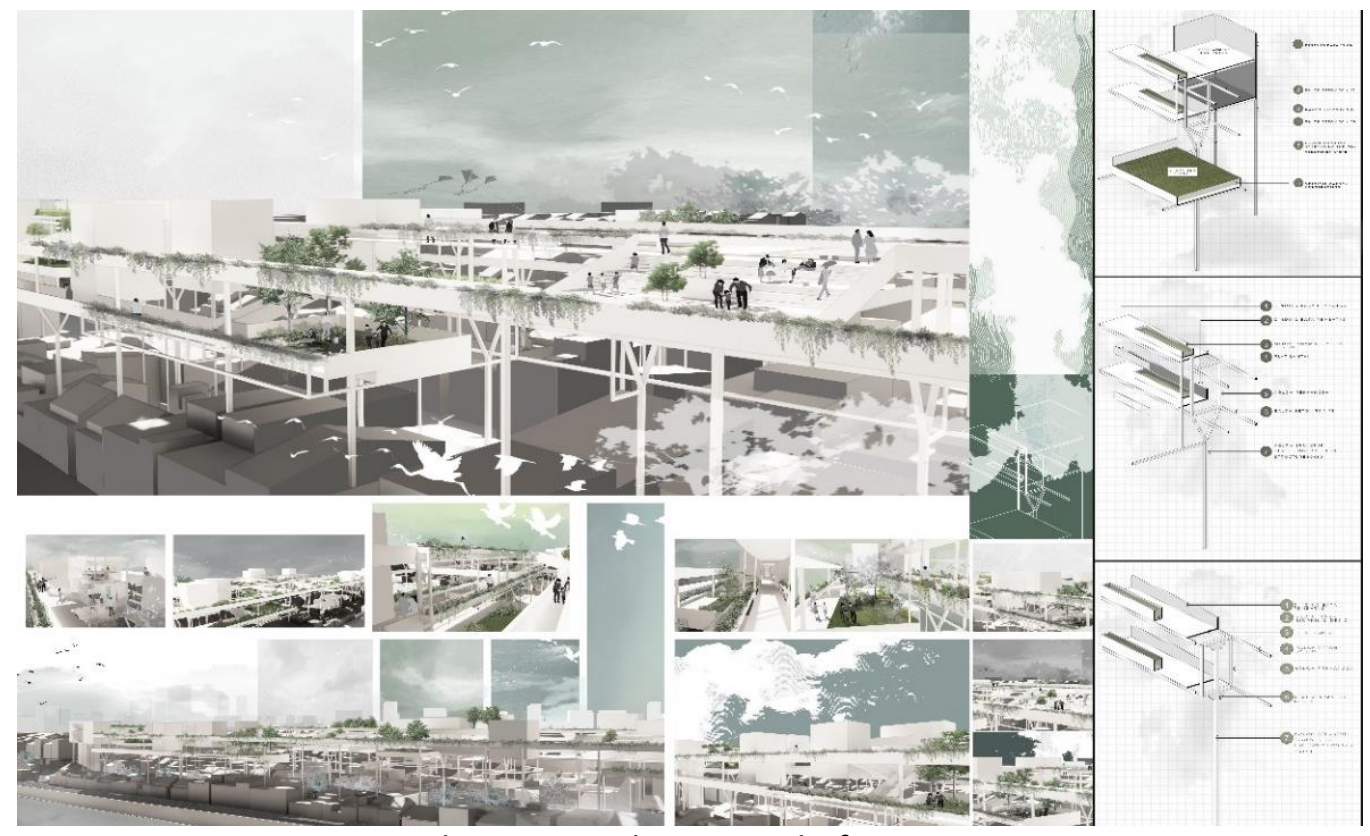

Gambar 10. Gambar Perspektif Bangunan

Sumber: Penulis, 2020.

\section{KESIMPULAN \& SARAN}

\section{Kesimpulan}

Sebuah proyek yang berfokus untuk menciptakan sebuah ruang tumbuh masyarakat sector informal di Tambora. Perkembangan sebuah kota yang semakin kapitalis, sehingga ketimpangan sebuah sector informal dengan sector formal yang sangat besar. Dengan pendekatan sebuah Urban Accupunchture, proyek ini berharap dapat menjadi sebuah wadah yang dapat menyembuhkan sebuah titik-titik dari perkotaan yang rusak, sehingga keberlangsungan sebuah kota dapat seimbang. Proyek ini berperan penting untuk menyediakan sebuah ruang tumbuh masyarakat, dimana masyarakat dapat dengan bebas beraktifitas dan berinteraksi dengan sebuah wadah yang terjamin. Sebuah kebutuhan akan sebuah ruang yang layak, untuk menjamin sebuah kesehatan tubuh maupun mental setiap individu, sebuah ruang ketiga dimana setiap masyarakat dapat kesempatan untuk rehabilitasi, berinteraksi, dan terinspirasi. 


\section{Saran}

Sebuah kota yang sudah semakin kapitalis perkembangannya, dimana banyaknya sebuah ketimpangan sosial, terutama pada sector informal. Sektor informal yang sudah semakin menjadi sebuah kaum pekerja paksa, dimana istilah tersebut ditujukan untuk mereka yang setiap saat bekerja dengan upah rendah serta lingkungan hidup yang buruk. Sebuah peran Arsitektur menjadi sebuah dasar ilmu yang sangat penting berperan dalam permasalahan ini. Arsitektur yang dapat dipergunakan lebih luas untuk menjangkau permasalahan sektor informal maupun golongan lainnya di dalam sebuah kota.

\section{REFERENSI}

Casagrande, M. (2015). Paracity- Urban Acupunchture. New York, Amerika Serikat (USA) : Oil Forest League

Lim, C.J. (2005). Neo Architecture-Studio 8 Architect. Australia: Image Publisher Group Pty. Ltd Kompasiana. (2006). Perkembangan Stratifikasi Sosial di Dunia. Jakarta, Indonesia. Diakses 20 Januari, dari https://www.kompasiana.com

Kompasiana. (2006). Perkembangan Stratifikasi Sosial di Dunia. Diakses 21 Januari, dari https://www.kompasiana.com/achmadpongsahidysaifullah/

Octavia, E.P. (2009). INTERAKSI SOSIAL \& Latar Belakangnya. Yogyakarta, Indonesia

Oldenburg, R. (1991). The Great Good Place. New York, Amerika Serikat (USA): Marlowe dan Company

PALLETE 2030. (2017). Urban Infill for City Growth. 2030 PALLETE, 1-3

Picon, A. (2015). Smart Cities: A Spatialized Intelligence. New Jersey, Amerika Serikat (USA): Wiley.

Pramono, D. (2007). Teori Anoniminitas pada Media Sosial. 2008: SKRIPSI ILMU KOMUNIKASI. $\mathrm{BAB}$ VI, 120- 123

Richard, J. (2007). The Magazine of the American Society of Landscape Architecture. Washington,D.C., Amerika Serikat (USA) : ASLA.

StichtingConstant. (2012). New Babylon. Diakses dari https://stichtingconstant.nl/newbabylon-1956-1974

Thisisrealarchitecture. (2012). Primitive Future Architecture The Improvised spaces of Sou Fujimoto. Diakses dari http://thisisrealarchitecture.blogspot. com/ 2012/ 08/primitivefuture- improvised-spaces -of.html.

Thisisrealarchitecture. (2012). Primitive Future Architecture Review Sou Fujimoto. Diakses dari http://thisisrealarchitecture.blogspot. com /2012/ 0123/ primitive- future- reviewhouse

Yona Friedman BIO. (2008). Ville Spatiale. Diakses dari http://www.yonafriedman.nl/?page_id=78 
